\title{
Comparative Inhibition Study by Nanomaterial, Plant Extract and Chemical Microcide on the Screaming Mummy in Egyptian Museum Store
}

\author{
Sahar Ismael ${ }^{1, *}$, Ali Omar ${ }^{2}$ and Manal Maher ${ }^{3}$ \\ 1 Conservation Department, Faculty of Archaeology, Fayoum University, Fayoum 63514, Egypt \\ 2 Microbiology Department, Conservation Center, Grand Egyptian Museum, Giza 12572, Egypt; \\ Dr.Ali_omar@yahoo.com \\ 3 Nanotechnology Center, Cairo University, Giza 12585, Egypt; manal.a.maher@gmail.com \\ * Correspondence: sma17@fayoum.edu.eg
}

check for updates

Citation: Ismael, S.; Omar, A.; Maher, M. Comparative Inhibition Study by Nanomaterial, Plant Extract and Chemical Microcide on the Screaming Mummy in Egyptian Museum Store. Heritage 2021, 4, 2481-2493. https://doi.org/10.3390/ heritage 4030140

Academic Editors:

Christofilis Maggidis and Omar Abdel-Kareem

Received: 18 August 2021

Accepted: 13 September 2021

Published: 16 September 2021

Publisher's Note: MDPI stays neutral with regard to jurisdictional claims in published maps and institutional affiliations.

Copyright: (c) 2021 by the authors. Licensee MDPI, Basel, Switzerland. This article is an open access article distributed under the terms and conditions of the Creative Commons Attribution (CC BY) license (https:// creativecommons.org/licenses/by/ $4.0 /)$.

\begin{abstract}
Mummies in museums are exposed to different deterioration factors like microorganisms, especially unwrapped mummies, such as the screaming mummy. This screaming mummy in the store of the Egyptian museum is suffering from stains due to microbial infection. There are three trends of materials to inhibit microbial growth: nano materials, plant extraction and chemical materials. This research compares three materials representing the three trends such as nano zinc oxide (ZnO-NPs), Ceratophyllum demersum and 4-chloro-m-cresol, respectively. Microorganisms, isolated from the degraded mummy, were identified with an optical microscope and ribosomal ribonucleic acid (rRNA) analysis to guarantee identification accuracy. Results indicated that the bacteria in the mummy are Bacillus jeotgali, Kocuria turfanensis, Microbacterium imperial, Micrococcus luteus and Bacillus megaterium. Fungi are Monascus pallens and Rhizopus oryzae. The results of minimum inhibitory concentration (MIC) illustrated that the best concentrations for the bio treatment of isolated microorganisms is plant extract (Ceratophyllum demersum) at $600 \mathrm{ppm} / 100 \mathrm{~mL}$, followed by 4-chloro-m-cresol at $600 \mathrm{ppm} / 100 \mathrm{~mL}$ and finally nano zinc oxide at $700 \mathrm{ppm} / 100 \mathrm{~mL}$.
\end{abstract}

Keywords: nano zinc oxide; Ceratophyllum demersum; 4-chloro-m-cresol; bacteria; fungi

\section{Introduction}

Mummification is a process that was done to preserve dead body in ancient Egypt by embalming and wrapped with linen bandages [1]. The ancient Egyptians did this process due to religious concepts, such as the afterlife [2]. Mummification includes the treatment of the body with oils, resin and wax wrapped with linen and placing it in a sealed coffin to ensure the preservation of the body [3]. Screaming (Glaring) mummies do not have good embalming. There are two types of screaming mummies: the first and most famous ones were murdered because of committing a crime, so they do not have good mummification or linen wrapping. The second type died as a result of a disease and all the usual embalming steps are done for them [4].

The mummy suffers from several factors that cause deterioration in museums, for example microorganisms [5], especially fungi more than bacteria. These organisms produce enzymes that cause staining and a decayed mummy [6]. The damage percentage by microorganisms depends on species, the surrounding climate (humidity, temperature) and the quality of the embalming $[7,8]$. Screaming mummies of the first type are more exposed to deterioration by fungi and bacteria because of bad mummification especially because they were not wrapped in linen strips.

The main concern of the study is the mummy of an unknown woman (Figure 1) from the store of the Egyptian Museum in Cairo, Egypt. The mummy's number is CIT 8; it was discovered in an unknown tomb by Winlock's excavations at ThT71. Winlock's written 
note cards say: S.A.K. (1935-1936) Servants Cemetery burial No. 2 (SENMUT) of the 18 th Dynasty. The height of the mummy is $158 \mathrm{~cm}$ (height from the heel to the crown of the head), and the age was estimated in the elderly.
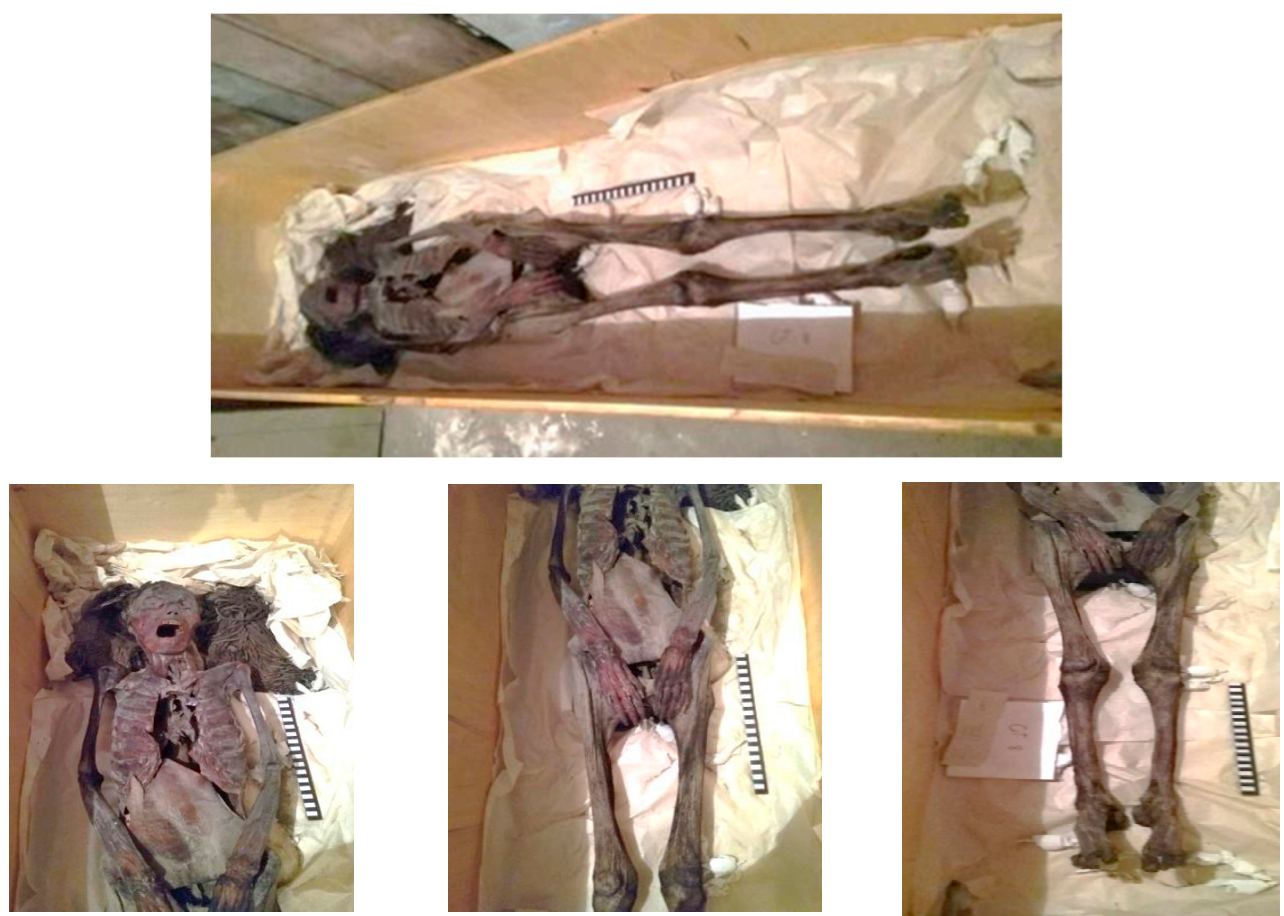

Figure 1. The screaming mummy from the 18th dynasty in the Egyptian museum store.

Lately, nano materials are used as an antimicrobial agent [9]. Nanomaterials (1-100 nm) have a lot of properties: reducing UV effects, consolidation, cleaning, deacidification and inhibition of microbial growth [10-13]. Nano zinc oxide (ZnO-NPs) is known as a good antimicrobial Aaent, [14] especially for leather [15]—thus, it was chosen for the current study.

Ancient Egyptians used plants that have antimicrobial activities (due to contents of phenols and esters) and essential oils for mummification [16]. Currently, plant extracts and essential oils are used as antimicrobial agents in different ways for archaeological objects. A plant extract is prepared byusing different parts of the plant (often the leaves) soaked in $100 \mathrm{~mL}$ of water and $100 \mathrm{~mL}$ of ethanol, then evaporated to obtain a substance dissolved in $200 \mathrm{~mL}$ of sterile distilled water. Essential oils are more effective for inhibiting microbial growth, but they are not suitable for every archaeological materials. They can cause darkening in color [17]. Scientific studies have mentioned that camphor and thyme are more effective than other essential oils $[18,19]$. Another study proved that plant extract and nano materials did not change or produce a reaction with archaeological objects' color [20]. Thus, it was chosen for the current study.

Some of hydrophytes in the Nile River have antimicrobial activity, including Ceratophyllum demersum [21]. Ceratophyllum demersum is a submerged aquatic plant from Saluga and Ghazal island [22]; they are protected areas in Aswan, Egypt [23].

There are a lot of chemical materials used as antimicrobials and pesticides. Some of them could be used in the treatment of archaeological objects. It is preferable to use safe antimicrobials for objects as a restorer, such as 4-chloro-m-cresol [24]. 4-chloro-m-cresol is considered a safe material to be used even in cosmetic products (up to $0.2 \%$ ). This material is a synonym for p-chloro-m-cresol $[25,26]$.

The current research aims to study microorganisms isolated from the screaming mummy and to study its biological activities. The study also aims to compare the inhibition of three materials: nano zinc oxide, Ceratophyllum demersum and 4-chloro-m-cresol 
representing, respectively. These three materials are for inhibiting microbial attacks, and are applied to the microorganisms isolated from the screaming mummy.

\section{Materials and Methods}

\subsection{Materials}

The nano material used in this study, zinc oxide ( $\mathrm{ZnO}-\mathrm{NPs})<50 \mathrm{~nm}$ particle size (BET), >97\%, was purchased from Sigma-Aldrich Company, No: 677450. The plant extract was Ceratophyllum demersum. The plant is a dominant species within the Nile River system. The plant was collected from sites located around Isis island $\left(24^{\circ} 04.646^{\prime} \mathrm{N} ; 32^{\circ} 52.701^{\prime} \mathrm{E}\right)$ and Saluga and Ghazal island $\left(24^{\circ} 04.328^{\prime} \mathrm{N} ; 32^{\circ} 52.279^{\prime} \mathrm{E}\right)$. It was prepared by washing the plant, then it was dried and ground into a powder. The powder was then left in methanol. The chemical antimicrobial was 4-chloro-m-cresol, purchased from Loba Chemie Pvt. Ltd., Mumbai, India, No: 02750. The media used for isolation and purification were cellulose, protein and nutrient agar.

\subsection{Methods}

A collection of swabs was taken from the screaming mummy in the Egyptian Museum store, specifically from skin areas including the head, wig, rib cage, abdominal and pelvic cavity, right leg, left leg and mouth of the mummy as the presence of microbial lesions is clear in the form of brown spots (Figure 2). Microbial swabs were cultured on plates of cellulose, protein and nutrient agar media. Regarding isolation and purification, the growths that presented in the Petri dishes were taken separately and cultured on the same previous media in order to obtain the microorganisms in pure forms to complete the steps of characterization.

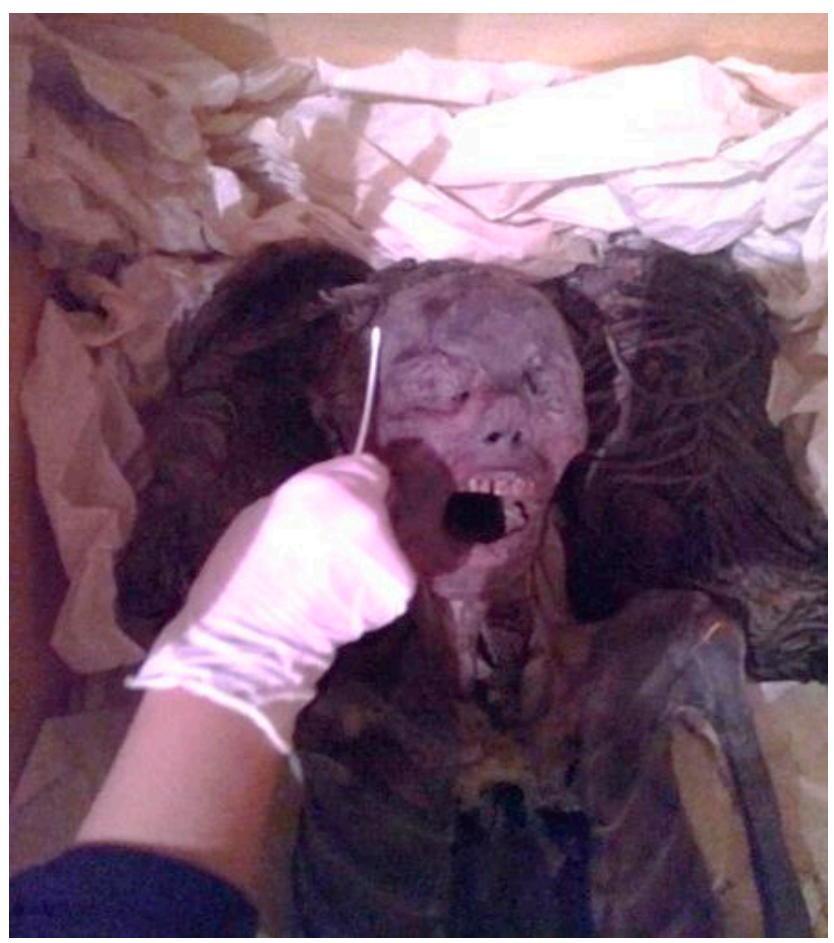

Figure 2. Collecting swabs from the mummy.

Microbial colonies that grew on the incubated plates were sub-cultured into separate fresh sterile cellulose agar and nutrient agar plates and then incubated to obtain pure cultures of causative microorganisms. The purified isolates were kept in slants and stored for characterization. Identification of all microbial isolates was carried out at the Laboratory of Microbiology, Grand Egyptian Museum, Ministry of Antiquities with optical microscopy and with sequencing of rRNA genes at Solgent Company, South Korea. 
Bacterial identification was performed with a molecular approach. Bacterial isolates were cultured in sterile test tubes containing $10 \mathrm{~mL}$ of nutrient broth medium [27]. Cultures were incubated at $28^{\circ} \mathrm{C}$ for $48 \mathrm{~h}$. A small amount of bacterial culture was scraped by sterile spatula suspended in $100 \mu \mathrm{L}$ of sterile distilled water in $2 \mathrm{~mL}$ of sterile vials and boiled at $100{ }^{\circ} \mathrm{C}$ for $15 \mathrm{~min}$. Bacterial DNA was extracted and isolated using SolGent purification bead. Prior to sequencing, the ribosomal rRNA gene was amplified using the polymerase chain reaction (PCR) technique in which two universal bacterial primers $27 \mathrm{~F}$ (forward) and 1492R (reverse) and were incorporated in the reaction mixture. Primers used for gene amplification have the following composition: 27F(5'AGAGTTTGATCMTGGCTCAG) and 1492R(5'TACGGYTACCTTGTTACGACTT).

The purified PCR products (amplicons) were reconfirmed using a size nucleotide marker (100 base pairs) by electrophoreses on $1 \%$ agarose gel. Then, these bands were eluted and sequenced with the incorporation of dideoxynucleotides (dd NTPs) in the reaction mixture. Each sample was sequenced in the sense and antisense directions using the same primers [28]. Sequences was further analyzed using Basic Local Alignment Search Tool (BLAST) from the National Center of Biotechnology Information (NCBI) website. Phylogenetic analysis of sequences was done with the help of Meg Align (DNA Star) software version 5.05. Identification of bacterial isolates was done by sequencing of rRNA genes at the Solgent Company, South Korea.

Fungal isolates can be identified with different methods (morphological, molecular approach and biochemical), but the molecular approach was used because of its high accuracy compared to the other methods. Fungal isolates were cultivated in Petri plates containing $20 \mathrm{~mL}$ of Czapek's yeast extract agar with $20 \%$ sucrose (CY20S) medium at $28^{\circ} \mathrm{C}$ for 7 days [29]. A small amount of fungal culture was scraped by sterile spatula suspended in $100 \mu \mathrm{L}$ sterile distilled water in $2 \mathrm{ml}$ sterile vials and boiled at $100^{\circ} \mathrm{C}$ for 15 min. Fungal DNA was extracted and isolated using SolGent purification bead. Prior to sequencing, the ribosomal rRNA gene was amplified using the polymerase chain reaction (PCR) technique in which two universal fungal primers were sequenced with ITS1 and ITS4 primers [30], which were incorporated in the reaction mixture. Primers used for gene amplification have the following composition: ITS1 (5'-TCCGTAGGTGAACCTGCGG3') and ITS4 (5'-TCC TCCGCTTATTGATATGC-3') for fungi.

The purified PCR products (amplicons) were reconfirmed using a size nucleotide marker (100 base pairs) by electrophoreses on $1 \%$ agarose gel. The amplicons were sequenced with the incorporation of dideoxynucleotides (dd NTPs) in the reaction mixture. Sequences were further analyzed using Basic Local Alignment Search Tool (BLAST) from the National Center of Biotechnology Information (NCBI) website. Phylogenetic analysis of sequences was done with the help of MegAlign (DNA Star) software version 5.05. Identification of fungal isolates was done by sequencing of rRNA gene at the Solgent Company, South Korea.

In order to determine cellulose (s) and protease activity of the isolated microorganisms we used the following steps:

\section{- Enzyme Production}

Production was carried out in $250 \mathrm{~mL}$ conical flasks. Each contained $100 \mathrm{~mL}$ of the production medium for producing cellulase and protease enzymes and the main source of carbon (sucrose) was replaced with $10 \mathrm{~g}$ of cellulose and $10 \mathrm{~g}$ of gelatin, respectively. Flasks were sterilized at $121^{\circ} \mathrm{C}$ for $15 \mathrm{~min}$. After that, cooling inoculated with $2 \mathrm{ml}$ of standard inoculums of each isolate. The inoculated flasks were incubated at $28-30^{\circ} \mathrm{C}$ for the proper time. At the end of the incubation period, the liquid cultures were centrifuged at 3000 RPM for $15 \mathrm{~min}$. The supernatant was taken for determination of enzyme (cellulase and protease) activity as described below.

- Enzymes Assay

The cup plate clearing zone technique (CCZ) was used for assaying activities of cellulase and protease enzymes. The procedure was carried out by pouring $20 \mathrm{~mL}$ aliquots 
of the detection medium [31] into a sterile Petri dish and it was then allowed to solidify. A sterile cork borer ( $15 \mathrm{~mm}$ diameter) was used to make three cups in each plate and $0.1 \mathrm{~mL}$ of the supernatant (cell free enzyme) of each isolate was placed into the three cups. Plates were incubated at $30^{\circ} \mathrm{C}$ for $24 \mathrm{~h}$ after which the plates were flooded with a Lugol's iodine solution to assay cellulose and with an acid mercuric chloride solution for protease assay. Enzyme activities were compared based on the diameter $(\mathrm{mm})$ of clear zone.

2.2.1. Determine Minimal Inhibitory Concentration (MIC) of Antimicrobial Agents against the Isolated Microorganisms

The three substances categories microcides chosen were: nano material, plant extract and chemical antimicrobial (ZnO NPs, Ceratophyllum demersum and 4-chloro-m-crysol) prepared to determine their minimal inhibitory concentrations. A stock solution of each microcide was prepared by dissolving $1 \mathrm{~g} / \mathrm{L}$ ethyl alcohol (95\%) in the case of 4-chloro-mcrysol and nano zinc oxide and $1 \mathrm{~mL} / \mathrm{L}$ of ethyl alcohol (95\%) in the case of Ceratophyllum demersum. Gradient concentrations of each microcide (400, 500, 600 and 700 ppm) were prepared by diluting the stock solution with alcohol.

One milliliter of spore suspension was spread on nutrient agar and Dox's agar plate. The controls were the solvents used for every extract. Plates were left to be dry. A cork borer was used to make three pores in each plate and $100 \mu \mathrm{L}$ of the three concentrations was added for each microcide materials. Concentrations start with $400 \mathrm{ppm} / 100 \mathrm{~mL}$. The zones of growth inhibition around the wells were measured after 18 to $24 \mathrm{~h}$ of incubation at $37^{\circ} \mathrm{C}$ for bacteria and 48 to $96 \mathrm{~h}$ for fungi at $28^{\circ} \mathrm{C}$. The sensitivities of the microorganism species to the test substances were determined by the sizes of inhibition zones (including the diameter of well) on the agar surface around the wells. Values less than $15 \mathrm{~mm}$ were considered as not active against microorganisms compared to control plates that used ethyl alcohol (dissolvent solution of microcides) alone.

\subsubsection{Evaluate Treatment for Isolated Microorganisms from Mummy}

Microbial growth was examined by taking of swabs from each treated plates after $48 \mathrm{~h}, 3$ months and 6 months. The swabs were cultured in Dox's medium for fungi and Nutrient agar for bacteria. A concentration of the best microcide will be used.

\section{Results}

\subsection{Identification of the Microbial Isolates}

\subsubsection{Optical Microscope Identification}

The resulting microbial colonies were subjected to preliminary characterization depending on the type of organism, as mentioned previously. The following genera were identified: bacillus, coccus and Rhizopus (Table 1 and Figures 3 and 4).

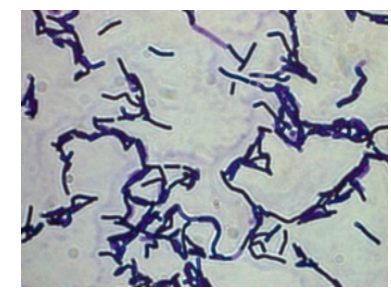

Bacillus megaterium

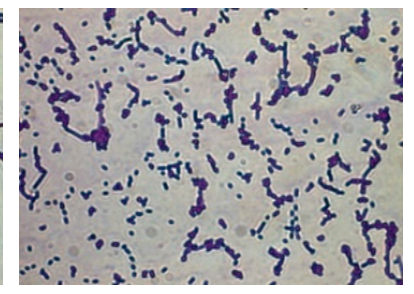

Microbacterium imperiale

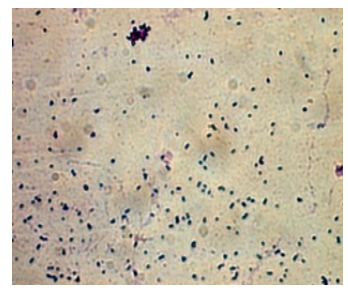

Kocuria turfanensis

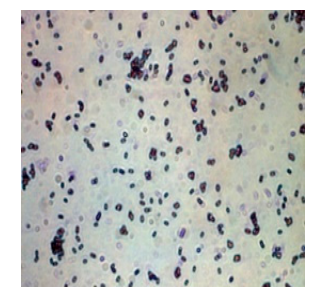

Bacillus jeotgali

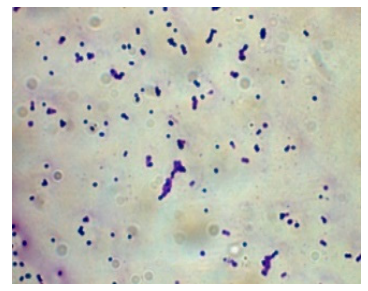

Micrococcus luteus

Figure 3. Bacteria isolated from mummy with optical microscope at $1000 \times$ magnification.

Based on the results, it can be seen that the genus bacillus was the dominant genus in seven sites having $33.3 \%$ of the total bacterial isolates and the genus Rhizopus was the dominant genus in seven sites having $55.2 \%$ of the total fungal isolates. 


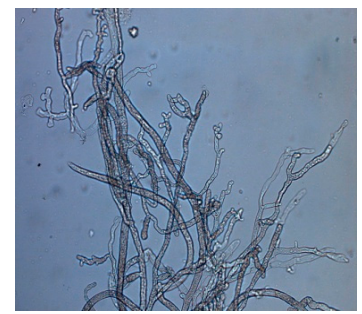

Monascus pallens

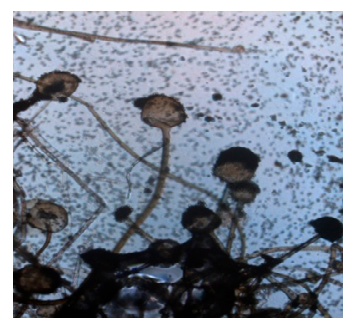

Rhizopus oryzae

Figure 4. Fungi isolated of mummy with optical microscope at $400 \times$ magnification.

Table 1. Isolated microorganisms grow on different media (cellulose, protein and nutrient agar).

\begin{tabular}{|c|c|c|c|}
\hline \multirow{2}{*}{ Swab Cite } & \multicolumn{3}{|c|}{ Media Used } \\
\hline & Cellulose Agar & Protein Agar & Nutrient Agar \\
\hline Head & $\begin{array}{c}\text { Fungus } 1 \\
\text { Rhizopus oryzae }\end{array}$ & $\begin{array}{l}\text { G+ve Shortbacilli } \\
\text { spore former1 }\end{array}$ & $\begin{array}{l}\text { G+ve Shortbacilli } \\
\text { spore former2 } \\
\text { Microbacillus spp. }\end{array}$ \\
\hline Wig & $\begin{array}{l}\text { Microbacillus spp. } \\
\text { Fungus } 1\end{array}$ & $\begin{array}{l}\text { Microbacillus spp. } \\
\text { G+ve Shortbacilli } \\
\text { spore former3 }\end{array}$ & $\begin{array}{c}\text { G+ve Shortbacilli } \\
\text { spore former3 }\end{array}$ \\
\hline Rib cage & Rhizopus oryzae & $\begin{array}{l}\text { G+ve Shortbacilli } \\
\text { spore former2 }\end{array}$ & $\begin{array}{l}\text { G+ve Shortbacilli } \\
\text { spore former4 } \\
\text { Microbacillus spp. }\end{array}$ \\
\hline $\begin{array}{l}\text { Abdominal and } \\
\text { pelvic cavity }\end{array}$ & Fungus 1 & Microbacillus spp. & $\begin{array}{c}\text { G+ve Shortbacilli } \\
\text { spore former3 } \\
\text { Micrococus spp. }\end{array}$ \\
\hline Right leg & Rhizopus oryzae & $\begin{array}{l}\text { Microbacillus spp. } \\
\text { G+ve Shortbacilli } \\
\text { spore former1 }\end{array}$ & $\begin{array}{c}\text { G+ve Shortbacilli } \\
\text { spore former3 }\end{array}$ \\
\hline Left leg & $\begin{array}{l}\text { Rhizopus oryzae } \\
\text { Microbacillus spp. }\end{array}$ & $\begin{array}{l}\text { G+ve Shortbacilli } \\
\text { spore former3 } \\
\text { G+ve Shortbacilli } \\
\text { spore former4 }\end{array}$ & $\begin{array}{c}\text { G+ve Shortbacilli } \\
\text { spore former3 } \\
\text { Microbacillus spp. }\end{array}$ \\
\hline Mouth & $\begin{array}{l}\text { Rhizopus oryzae } \\
\text { Fungus } 1\end{array}$ & Micrococus spp. & $\begin{array}{l}\text { G+ve Shortbacilli } \\
\text { spore former2 } \\
\text { Micrococus spp. }\end{array}$ \\
\hline
\end{tabular}

\subsection{2. rRNA Sequencing Identification}

Based on the results in Tables 2 and 3, it was found that the bacterial isolates were identified according to thew molecular approach by $16 \mathrm{~S}$ rRNA sequencing analysis compared with closely related strains accessed from the Gen Bank, such as Bacillus jeotgali, Kocuria turfanensis, Microbacterium imperial, Micrococcus luteu and Bacillus megaterium. Fungal isolates were identified according to the molecular approach by ITS region of rDNA sequencing analysis and compared with closely related strains accessed from the Gen Bank, such as Monascus pallens and Rhizopus oryzae.

\subsection{Determination of Cellulases and Protease Produced by the Isolated Microorganisms by Cup Plate Technique}

Data recorded in Table 4 and illustrated by Figure 5 indicate that the tested microorganisms proved the various abilities to produce the cellulases and protease enzymes. Microorganisms are different in the degree of decomposition of proteins and cellulose. The tabulated data show the highest activity of cellulolytic activity observed in Bacillus jeotgali and a highest activity of proteolytic activity observed in Microbacterium imperial. 
Table 2. Identification of bacterial isolates obtained from deteriorated mummy by $16 \mathrm{~S}$ rRNA sequencing analysis compared with closely related strains accessed from the Gen Bank.

\begin{tabular}{|c|c|c|c|c|}
\hline \multirow[t]{2}{*}{ Swab Cite } & \multirow[t]{2}{*}{ Identification } & \multicolumn{3}{|c|}{$\begin{array}{l}\text { Closely Related Microbial Strains Accessed } \\
\text { from Gen Bank }\end{array}$} \\
\hline & & Strain No. & Accession No. & Similarity \\
\hline \multirow{3}{*}{ Head } & Bacillus jeotgali & YKJ-10 & NR025060T & $99.93 \%$ \\
\hline & Kocuria turfanensis & HO-9042 & NR043899T & $88.22 \%$ \\
\hline & Microbacterium imperiale & DSM 20530 & NR026161T & $99.86 \%$ \\
\hline \multirow{2}{*}{ Wig } & Microbacterium imperiale & DSM 20530 & NR026161T & $99.86 \%$ \\
\hline & Bacillus jeotgali & YKJ-10 & NR025060T & $99.93 \%$ \\
\hline \multirow{2}{*}{ Rib cage } & Microbacterium imperiale & DSM 20530 & NR026161T & $99.86 \%$ \\
\hline & Bacillus jeotgali & YKJ-10 & NR025060T & $99.93 \%$ \\
\hline \multirow{3}{*}{$\begin{array}{l}\text { Abdominal and } \\
\text { pelvic cavity }\end{array}$} & Microbacterium imperial & DSM 20530 & NR026161T & $99.86 \%$ \\
\hline & Micrococcus luteu & MB5 & MH450098 & $99.71 \%$ \\
\hline & Bacillus jeotgali & YKJ-10 & NR025060T & $99.93 \%$ \\
\hline \multirow{3}{*}{ Right leg } & Bacillus megaterium & $\begin{array}{c}\text { NBRC } 15308= \\
\text { ATCC } 14581\end{array}$ & NR112636T & $100 \%$ \\
\hline & Microbacterium imperial & DSM 20530 & NR026161T & $99.86 \%$ \\
\hline & Kocuria turfanensis & HO-9042 & NR043899T & $88.22 \%$ \\
\hline \multirow{3}{*}{ Left leg } & Microbacterium imperial & DSM 20530 & NR026161T & $99.86 \%$ \\
\hline & Bacillus jeotgali & YKJ-10 & NR025060T & $99.93 \%$ \\
\hline & Bacillus megaterium & $\begin{array}{l}\text { NBRC } 15308= \\
\text { ATCC } 14581\end{array}$ & NR112636T & $100 \%$ \\
\hline \multirow{2}{*}{ Mouth } & Bacillus jeotgali & YKJ-10 & NR025060T & $99.93 \%$ \\
\hline & Micrococcus luteus & MB5 & MH450098 & $99.71 \%$ \\
\hline
\end{tabular}

Table 3. Identification fungal isolates obtained from deteriorated mummy ITS region of rDNA sequencing analysis compared with closely related strains accessed from the Gen Bank.

\begin{tabular}{ccccc}
\hline \multirow{2}{*}{ Scheme } & Identification & \multicolumn{3}{c}{ Closely Related Microbial Strains Accessed } \\
& & \multicolumn{3}{c}{ from Gen Bank } \\
\cline { 3 - 5 } & Monascus pallens & Strain No. & Accession No. & Similarity \\
\hline \multirow{2}{*}{ Head } & Rhizopus oryzae & IMI 356820 & GU733328 & $100 \%$ \\
& IDI 354840 & GU732332 & $99.88 \%$ \\
\hline \multirow{2}{*}{ Wig } & Microbacterium imperial & DSM 20530 & NR026161T & $99.86 \%$ \\
& Monascus pallens & IMI 356820 & GU733328 & $100 \%$ \\
\hline Rib cage & Rhizopus oryzae & IDI 354840 & 2GU732332 & $99.88 \%$ \\
\hline Abdominal and & Monascus pallens & IMI 356820 & GU733328 & $100 \%$ \\
\hline pelvic cavity & Rhizopus oryzae & IDI 354840 & GU732332 & $99.88 \%$ \\
\hline \multirow{2}{*}{ Left leg } & Microbacterium imperial & DSM 20530 & NR026161T & $99.86 \%$ \\
& Rhizopus oryzae & IDI 354840 & GU732332 & $99.88 \%$ \\
\hline \multirow{2}{*}{ Mouth } & Monascus pallens & IMI 356820 & GU733328 & $100 \%$ \\
& Rhizopus oryzae & IDI 354840 & GU732332 & $99.88 \%$ \\
\hline
\end{tabular}

\subsection{The MIC of Isolated Micro-Organisms}

In this part of the study, the three microcides were applied to the isolated microorganisms to determine the MIC. Nano zinc oxide showed no response at various concentrations $(400,500$ and $600 \mathrm{ppm} / 100 \mathrm{~mL})$ in all isolates, except for at the concentration $700 \mathrm{ppm} / 100 \mathrm{~mL}$ that showed a response to all isolates. Thus, it could be reported that using nano zinc oxide at concentrations of $700 \mathrm{ppm} / 100 \mathrm{~mL}$ gave the diameter of a clear zone that ranged from $18-25 \mathrm{~mm}$. 
Table 4. Determine of cellulases and protease produced by the isolated microorganisms using cup plate technique.

\begin{tabular}{ccc}
\hline \multirow{2}{*}{ Microbial Isolates } & \multicolumn{2}{c}{ Diameter of Clearing Zone (mm) } \\
\cline { 2 - 3 } & Cellulases & Protease \\
\hline Monascus pallens & 23 & 22 \\
Rhizopus oryzae & 24 & 21 \\
Bacillus jeotgali & 28 & 27 \\
Kocuria turfanensis & 19 & 20 \\
Microbacterium imperial & 26 & 32 \\
Micrococcus luteus & 24 & 25 \\
Bacillus megaterium & 22 & 21 \\
\hline
\end{tabular}

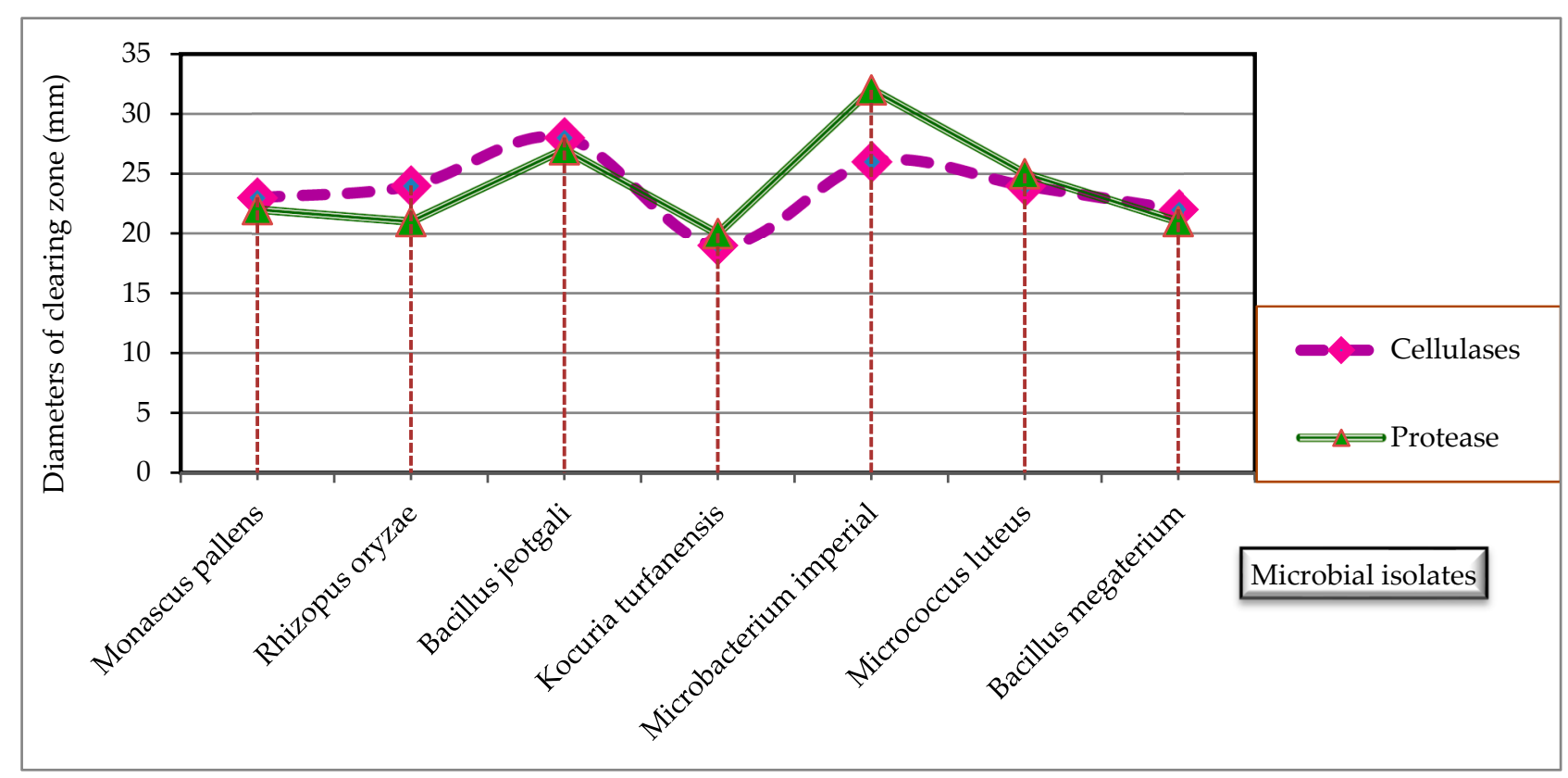

Figure 5. Cellulase(s) and protease produced by isolated microorganisms using cup plate technique.

Natural substance plant extract (Ceratophyllum demersum) had a good response at $600 \mathrm{ppm} / 100 \mathrm{~mL}$ concentration, which gave a response in all isolates. Therefore, it could be reported that using a natural substance at $600 \mathrm{ppm} / 100 \mathrm{~mL}$ gave the diameter of a clear zone ranging from $25-48 \mathrm{~mm}$.

In the case of 4-chloro-m-cresol, no response could be detected at $400 \mathrm{ppm} / 100 \mathrm{~mL}$ concentration of all isolated microorganisms. It showed a response at $500 \mathrm{ppm} / 100 \mathrm{~mL}$ with most isolated microorganisms, but the good response was at $600 \mathrm{ppm} / 100 \mathrm{~mL}$, where the diameter of a clear zone ranged from $24-45 \mathrm{~mm}$.

These data can be used to recommend the best concentrations of a specific microbicide for the microbial treatment of an infected mummy. For instance, a natural substance plant extract (Ceratophyllum demersum) at $600 \mathrm{ppm} / 100 \mathrm{~mL}$ is sufficient to inhibit all isolated microorganisms followed by 4-chloro-m-cresol at $600 \mathrm{ppm} / 100 \mathrm{~mL}$ and Nano zinc oxide at 700 ppm/100 mL. These results are listed in Table 5 and shown in Figures 6 and 7.

\subsection{Evaluation of Different Methods for Treatment of Deteriorated Mummy}

The plant extract was the best to be applied using the fumigation method $\left(30 \mathrm{~mL} / \mathrm{m}^{3}\right)$. A concentration of $600 \mathrm{ppm} / 100 \mathrm{~mL}$ of plant extract was used to inhibit microbial growth on the mummy. Microbial growth was examined by taking of swabs from each treated specimen after 48 h, 3 months and 6 months. The swabs were cultured in Dox's agar medium for fungi and Nutrient agar for bacteria (Table 6). 
Table 5. Determine inhibition zone ( $\mathrm{mm}$ ) of microbial species grown on Czapek agar and Nutrient agar as affected by three microcides: nano zinc oxide, natural plant extract (Ceratophyllum demersum) and 4-chloro-m-cresol.

\begin{tabular}{cccccccccccc}
\hline & \multicolumn{3}{c}{ Inhibition Zone by mm at Different Concentrations (ppm/100 mL). } \\
\cline { 2 - 10 } Microorganisms & \multicolumn{3}{c}{ Nano Zinc Oxide } & \multicolumn{3}{c}{ Plant Extract } & \multicolumn{3}{c}{ 4-chloro-m-cresol } \\
\cline { 2 - 10 } & $\mathbf{4 0 0}$ & $\mathbf{5 0 0}$ & $\mathbf{6 0 0}$ & $\mathbf{7 0 0}$ & $\mathbf{4 0 0}$ & $\mathbf{5 0 0}$ & $\mathbf{6 0 0}$ & $\mathbf{4 0 0}$ & $\mathbf{5 0 0}$ & $\mathbf{6 0 0}$ \\
\hline Monascus pallens & 0 & 0 & 0 & 18 & 0 & 20 & 37 & 0 & 25 & 35 \\
Rhizopus oryzae & 0 & 0 & 0 & 25 & 0 & 30 & 48 & 0 & 30 & 45 \\
$\begin{array}{c}\text { Bacillus jeotgali } \\
\text { Kocuria }\end{array}$ & 0 & 0 & 0 & 18 & 0 & 0 & 28 & 0 & 0 & 27 \\
$\begin{array}{c}\text { turfanensis } \\
\text { Microbacterium }\end{array}$ & 0 & 0 & 0 & 22 & 0 & 27 & 40 & 0 & 25 & 28 \\
$\begin{array}{c}\text { imperial } \\
\text { Micrococcus luteus } \\
\text { Bacillus }\end{array}$ & 0 & 0 & 0 & 0 & 22 & 0 & 33 & 43 & 0 & 25 & 32 \\
megaterium & 0 & 0 & 0 & 21 & 0 & 25 & 36 & 0 & 25 & 33 \\
\hline
\end{tabular}

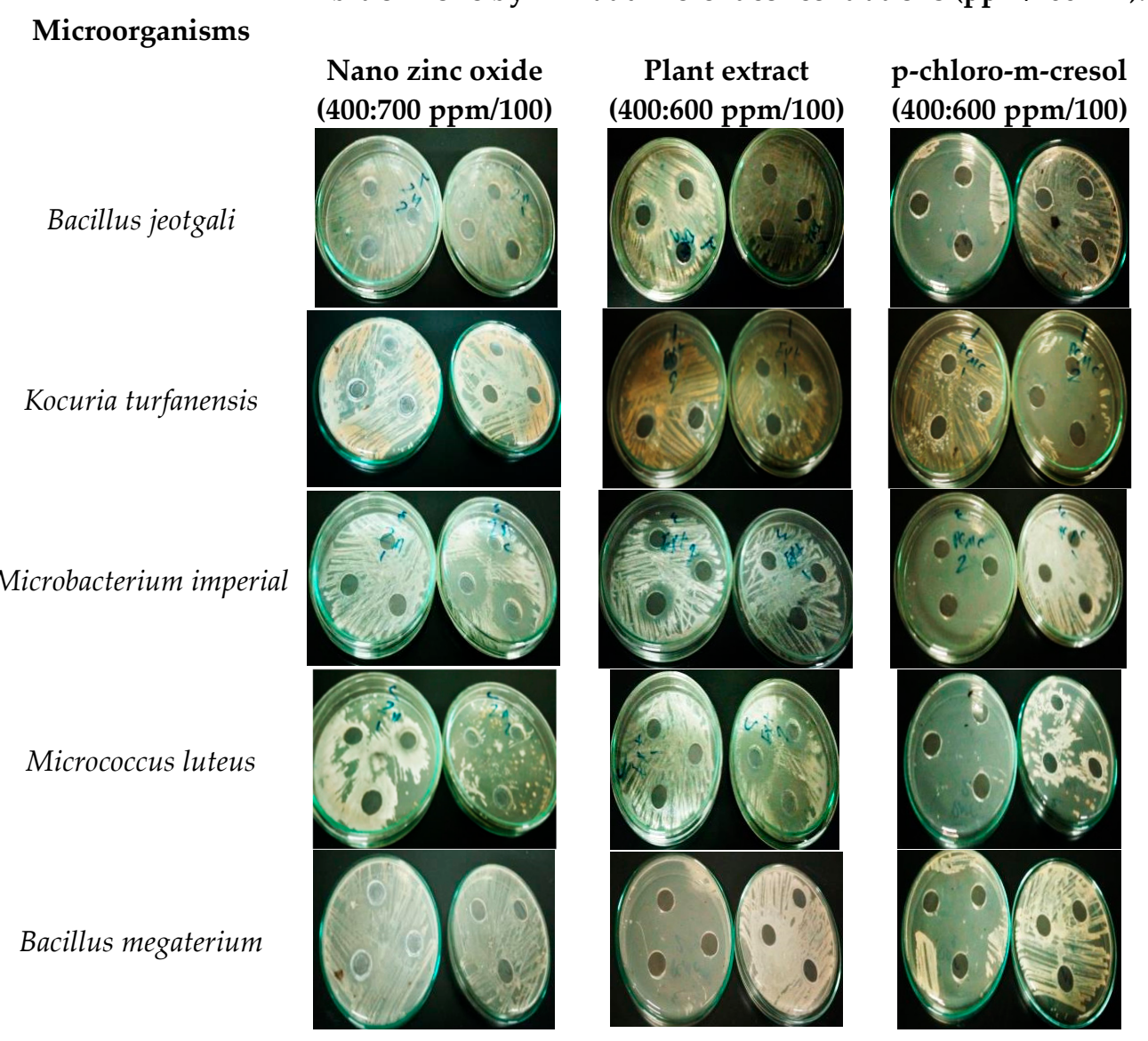

Figure 6. Effect of the three microcides: nano zinc oxide, natural plant extract (Ceratophyllum demersum) and 4-chloro-m-cresol on bacteria isolated from the mummy. 


\section{Microorganisms}

Monascus pallens

Rhizopus oryzae

Inhibition zone by $\mathbf{m m}$ at different concentrations (ppm/100 $\mathrm{mL}$ ).

Nano zinc oxide

(400:700 ppm/100)
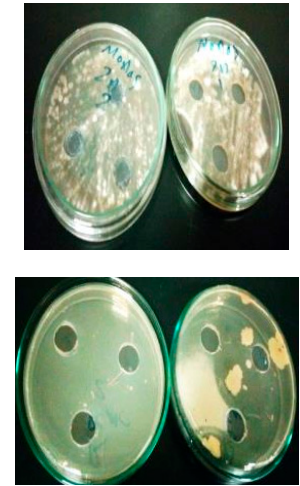

Plant extract

(400:600 ppm/100)
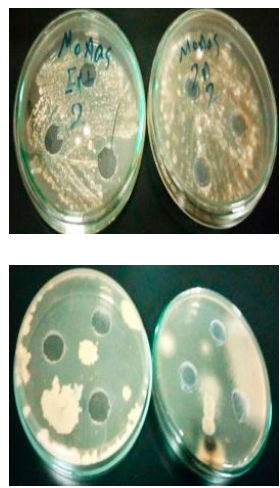

p-chloro-m-cresol

(400:600 ppm/100)
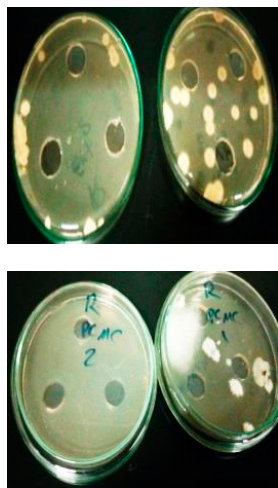

Figure 7. Effect of the three microcides: nano zinc oxide, natural plant extract (Ceratophyllum demersum) and 4-chloro-mcresol on fungi isolated from the mummy.

Table 6. The effect of applying Ceratophyllum demersum at (600 ppm/100 mL) on microbial growth isolated from mummy.

\begin{tabular}{cc}
\hline Growth Detection Time & $\begin{array}{c}\text { Growth of the Infectious Isolates after Treatment with } \\
\text { (Ceratophyllum demersum } \text { L.) at } \mathbf{6 0 0} \mathbf{~ p p m} / \mathbf{1 0 0} \mathbf{~ m L}\end{array}$ \\
\hline $48 \mathrm{~h}$ & No Growth \\
3 Month & No Growth \\
6 Month & No Growth \\
\hline
\end{tabular}

\section{Discussion}

Results show that the concentration $500 \mathrm{ppm} / 100 \mathrm{~mL}$ of nano zinc oxide does not have any effect, but the plant extract had the highest inhibition zone with most isolated microorganisms. In the concentration of $600 \mathrm{ppm} / 100 \mathrm{~mL}$, there is no response for nano zinc oxide as well, although the plant extract and chemical microcide have a good inhibition zone. Therefore, nano zinc oxide in the concentration $700 \mathrm{ppm} / 100 \mathrm{~mL}$ was compared to a concentration of $600 \mathrm{ppm} / 100 \mathrm{~mL}$ of the for natural Plant extract (Ceratophyllum demersum) and chemical microcide, 4-chloro-m-cresol (Figures 8 and 9).

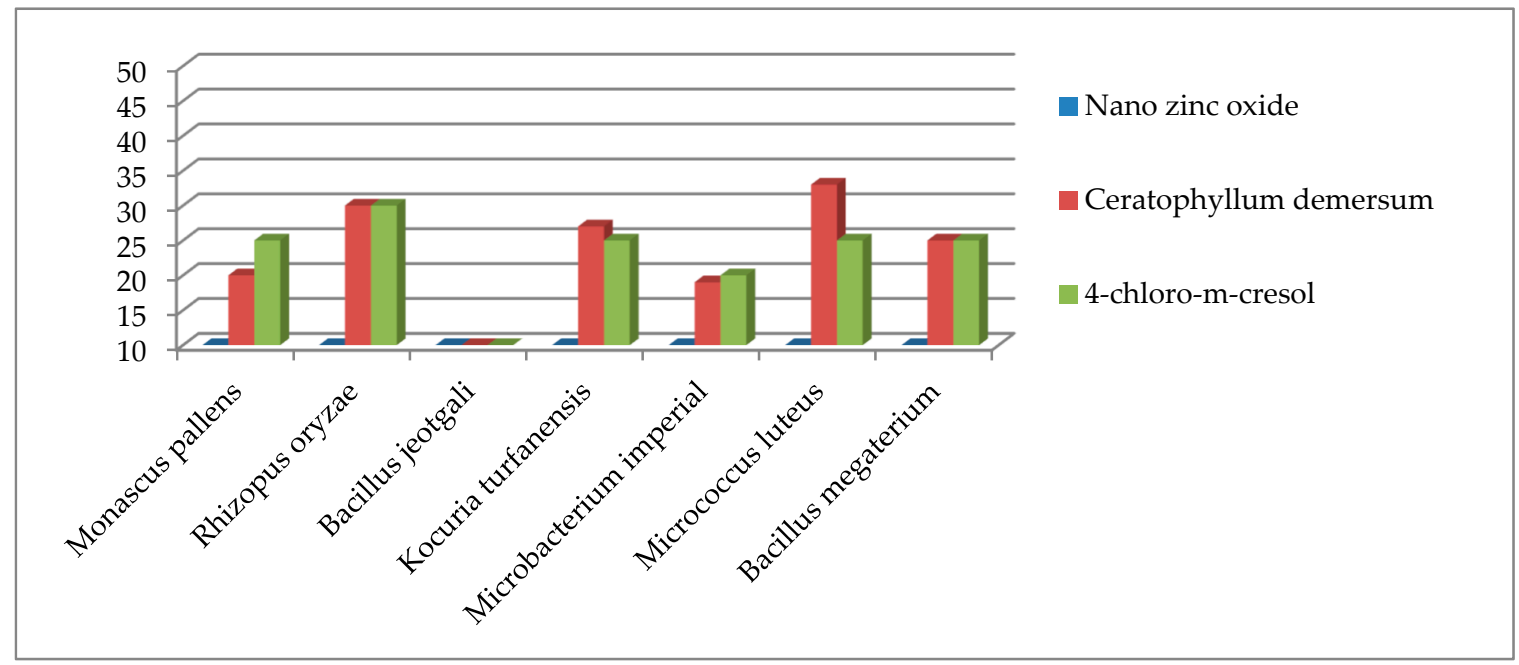

Figure 8. Comparison of the inhibition zone $(\mathrm{mm})$ of microbial species grown on Czapek agar and Nutrient agar as affected by the 500 ppm/100 mL concentration of three microcides: nano zinc oxide, Ceratophyllum demersum and 4-chloro-m-cresol. 


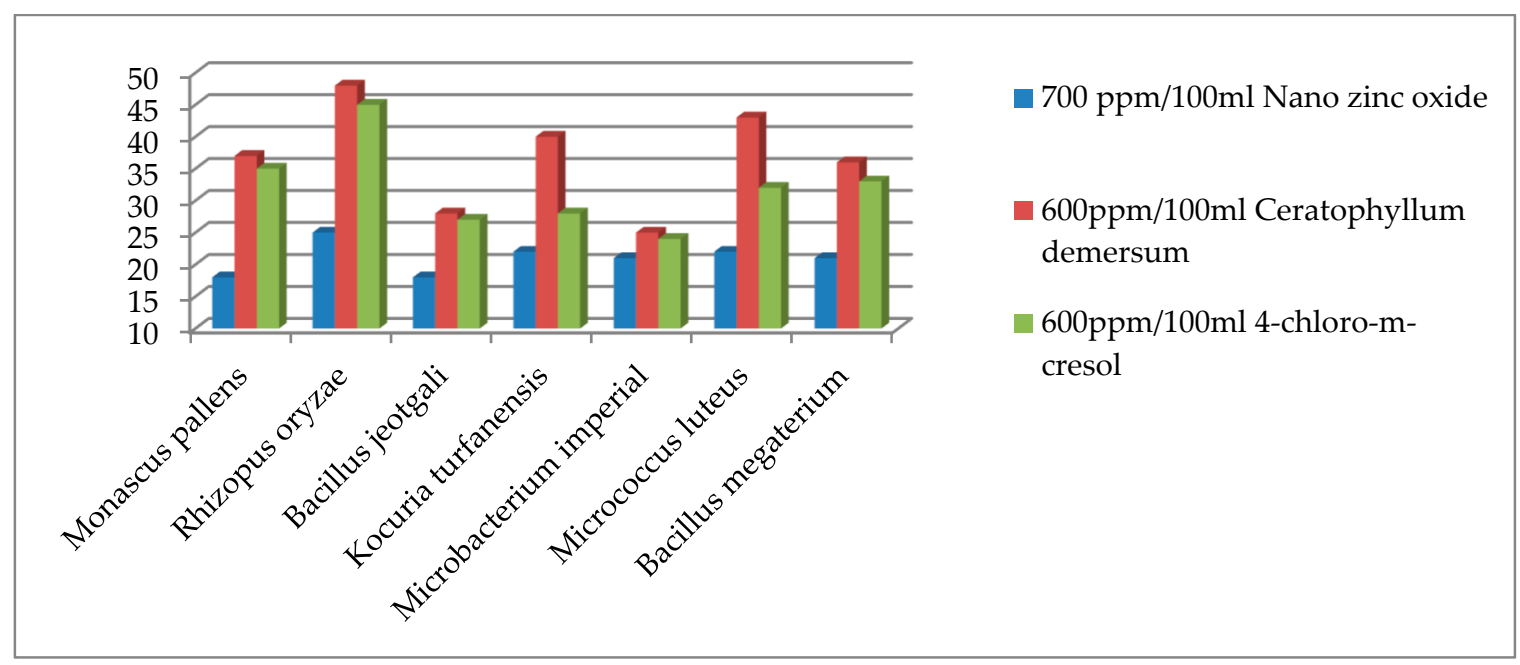

Figure 9. Comparison of the inhibition zone $(\mathrm{mm})$ of microbial species grown on Czapek agar and Nutrient agar as affected by the $700 \mathrm{ppm} / 100 \mathrm{~mL}$ nano zinc oxide and $600 \mathrm{ppm} / 100 \mathrm{~mL}$ concentration of Ceratophyllum demersum and 4-chloro-m-cresol.

The chemical microcide (4-chloro-m-cresol), applied by brush or spray, could be concentrated in places and forgotten in others. This material could have an effect on the restorer's health if they do not wear a mask. For that reason, the chemical microcide (4-chloro-m-cresol) was not used. The nano material (ZnO NPs) is safer than 4-chloro-mcresol for the restorer, but could be also concentrated in some places and cause a whitening of the mummy's appearance, especially if the mummy does not have wrapped linen.

Natural plant extracts (Ceratophyllum demersum) are used by fumigation in closed areas. A tent from polyethylene (plastic) was made and the mummy was put inside to be treated. Then, determining the volume of the tent in cubic meters and the corresponding volume of the plant extract is put into a Petri dish at the ratio of $30 \mathrm{~mL} / \mathrm{m}^{3}$. After that, the tent was sealed and left for $48 \mathrm{~h}$. Microbial growth was examined by taking swabs from each treated specimen after $48 \mathrm{~h}, 3$ months and 6 months. The swabs were cultured in Dox's medium for fungi and Nutrient agar for bacteria. This fumigation method is the best for archaeological objects that have many details, such as the screaming mummy. This mummy does not have wrapped linen strips. In addition, the Ceratophyllum demersum does not cause any change to the archaeological material's color and does not harm the restorer's health. This result is similar to the treatment of rare books [32].

\section{Conclusions}

The ancient mummies preserved in the Egyptian Museum store deteriorated due to the poor level of preservation conditions. Microorganisms isolated from the screaming mummy were identified based on ribosomal RNA analysis. Results show the presence of bacteria: Bacillus jeotgali, Kocuria turfanensis, Microbacterium imperial, Micrococcus luteus and Bacillus megaterium. The fungi are Monascus pallens and Rhizopus oryzae.

The isolated microorganisms produced activity in cellulose and protease enzymes that can cause biodeterioration of ancient mummies. The comparison between the three types of microcides material showed that the plant extract, Ceratophyllum demersum, at a concentration of $600 \mathrm{ppm} / 100 \mathrm{~mL}$ is the best. It is sufficient to inhibit all isolated microorganisms.

Author Contributions: Conceptualization, S.I.; methodology, S.I. and A.O.; software, S.I.; investigation, S.I.; data curation, S.I., A.O. and M.M.; writing-original draft preparation, S.I. and A.O.; writing-review and editing, S.I.; visualization, S.I. All authors have read and agreed to the published version of the manuscript.

Funding: This research received no external funding. 
Institutional Review Board Statement: Not applicable.

Informed Consent Statement: Not applicable.

Data Availability Statement: Not applicable.

Conflicts of Interest: The authors declare no conflict of interest.

\section{References}

1. Museum of Natural History Smithsonian Institution. Egyptian Mummies. 2012. Available online: https://www.si.edu/spotlight/ ancient-egypt/mummies (accessed on 15 May 2021).

2. Abdel-Maksoud, G.; El-Amin, A. A review on the materials used during the mummification processes in ancient Egypt. Mediterr. Archaeol. Archaeom. 2011, 11, 129-150.

3. Magdy, M.; Ismail, M.; Issa, Y.; Abdel-Maksoudc, G.; Ibrahim, M. An analytical study for understanding the degradation process of a late period mummy. Adv. Res. Conserv. Sci. 2020, 1, 13-30.

4. Hawass, Z.; Saleem, S. Computed tomography examination of the screaming mummy “Unknown-Woman-A”. Egypt. J. Radiol. Nucl. Med. 2020, 51, 139. [CrossRef]

5. Arya, A.; Shah, A.R.; Sadasivan, S. Indoor aeromycoflora of Baroda museum and deterioration of Egyptian mummy. Curr. Sci. 2001, 81, 793-799.

6. Naji, M.K.; Abdullah, Q.Y.; AL-Zaqri, A.Q. Evaluating the biodeterioration enzymatic activities of fungal contamination isolated from some ancient Yemeni mummies preserved in the national museum. Biochem. Res. Int. 2014, 2014, 481508. [CrossRef]

7. Omar, A.M.; Taha, A.S.; Mohamed, A.A. Microbial deterioration of some archaeological artifacts: Manipulation and treatment. Eur. J. Exp. Biol. 2018, 8, 21. [CrossRef]

8. Elamin, A.; Takatori, K.; Matsuda, Y.; Tsukada, M.; Kirino, F. Microbialogical, morphological and spectroscopic study on the effect of resinous materials in the preservation of wrapping textiles of mummies. Mediterr. Archaeol. Archaeom. 2018, 18, 1-10. [CrossRef]

9. David, M.E.; Ion, R.M.; Grigorescu, R.M.; Iancu, L.; Andrei, E.R. Nanomaterials used in conservation and restoration of cultural heritage: An up-to-date overview. Mater. J. 2020, 13, 2064. [CrossRef]

10. Bonini, M.; Lenz, S.; Giorgi, R.; Baglioni, P. Nanomagnetic sponges for the cleaning of works of art. Langmuir J. 2007, 23, 8681-8685. [CrossRef]

11. Giorgi, R.; Chelazzi, D.; Fratini, E.; Langer, S.; Niklasson, A.; Rådemar, M.; Svensson, J.E.; Baglioni, P. Nanoparticles of calcium hydroxide for wood deacidification: Decreasing the emissions of organic acid vapors in church organ environments. J. Cult. Herit. 2009, 10, 206-213. [CrossRef]

12. Helmi, F.M.; Ali, N.M.; Ismael, S.M. Nanomaterials for the inhibition of microbial growth on Ancient Egyptian Funeral masks. Mediterr. Archaeol. Archaeom. 2015, 15, 87-95. [CrossRef]

13. Sricharussin, W.; Threepopnatkul, P.; Neamjan, N. Effect of various shapes of zinc oxide on cotton fabric for UV-Blocking and anti-bacterial properties. Fibers Polym. J. 2011, 12, 1037-1041. [CrossRef]

14. Taghizadeh, S.M.; Lal, N.; Ebrahiminezhad, A.; Moeini, F.; Seifan, M.; Ghasemi, Y.; Berenjian, A. Green and economic fabrication of Zinc Oxide (ZnO) nanorods as a broadband UV blocker and antimicrobial agent. Nanomater. J. 2020, 10, 530. [CrossRef]

15. Khamseh, H. Conservation of leather historical object by Nano technology in archaeology found (Sample study cover leather book). J. Fundam. Appl. Sci. 2016, 8, 276-283. [CrossRef]

16. Mansour, M.M.; EL-Hefny, M.; Salem, M.; Ali, H.M. The Biofungicide activity of some plant essential oils for the cleaner production of model linen fibers similar to those used in ancient Egyptian mummification. Process. J. 2020, 8, 79. [CrossRef]

17. Othman, M.; Saadat, H.; Matsuda, Y. Antifungal activity of some plant extracts and essential oils against Fungi-Infested organic archaeological artefacts. Archaeometry 2020, 62, 187-199. [CrossRef]

18. Elsayed, Y.; Shabana, Y. The effect of some essential oils on aspergillus Niger and Alternaria Alternata infestation in archaeological oil paintings. Mediterr. Archaeol. Archaeom. 2018, 18, 71-87. [CrossRef]

19. Geweely, N.S.; Afifi, H.A.; Ibrahim, D.M.; Soliman, M.M. Efficacy of essential oils on Fungi isolated from archaeological objects in Saqqara excavation, Egypt. Geomicrobiol. J. 2019, 36, 148-168. [CrossRef]

20. Khalaphallah, R.; El-Derby, A. The effect of nano $\mathrm{TiO}_{2}$ and plant extracts on microbial strains isolated from Theban ancient Egyptian royal tomb painting. Afr. J. Microbiol. Res. 2015, 9, 1424-1430. [CrossRef]

21. Metwally, F.E.; Mohamed, A.A.; Mahalel, U.A.; Sheded, M.G. Evaluation of certain cosmopolitan hydrophytes in the Nile River, Aswan district for their ecological and bioactivity potentials: A review. Int. J. Sci. Technol. Res. 2020, 9, 1595-1606, ISSN $2277-8616$.

22. Omar, A.M.; Salah, T.A.; Mohamed, A.A.; Sheded, M.G. Attenuation of microbial induced deterioration of cellulose fibers by hornwort (Ceratophyllum demersum L.) methanolic extract. Int. J. Biol. Res. 2017, 5, 48-58. [CrossRef]

23. Abdel-wahab, H.M.; Abdel-kader, A.E.; Yousef, R.S. Population dynamics of terrestrial insects in Saluga and Ghazal protected area, Aswan, Egypt. Egypt. Soc. Environ. Sci. 2019, 18, 117-123.

24. Omar, A.; Taha, A.; El-Wekeel, F. Microbial degradation of ancient textiles in the Egyptian textile museum and methods of its control. Egypt. J. Archaeol. Restor. Stud. 2019, 9, 27-37. 
25. US EPA (United States Environmental Protection Agency). Reregistration Eligibility Decision (RED) p-Chloro-m-cresol, Prevention, Pesticides and Toxic Substances. EPA-738-R-96-008. 1997. Available online: https://archive.epa.gov/pesticides/ reregistration/web/pdf/3046red.pdf (accessed on 15 May 2021).

26. Andersen, F.A. Final report on the safety assessment of p-chloro-m-cresol. Int. J. Toxicol. 1997, 16, 268.

27. Zimbro, M.J.; Power, D.A.; Miller, S.M.; Wilson, G.E. and Johnson, J.A. Difco \& BBL Manual of Microbiological Culture Media, 2nd ed.; Becton, Dickinson and Company: New Jersey, MD, USA, 2009.

28. Lane, D.J. ; 16S/23S rRNA Sequencing. Nucleic Acid Techniques in Bacterial Systematics; John Wiley and Sons: Chichester, UK, 1991; pp. 115-175. Available online: http://lycofs01.lycoming.edu/ \{\}newman/NovelMicrobe/16SrRNAprimers.pdf (accessed on 15 June 2021).

29. Pitt, J.I.; Hocking, A.D. Fungi and Food Spoilage, 3rd ed.; Springer Science \& Business Media LLC: Berlin/Heidelberg, Germany, 2009.

30. White, T.J.; Bruns, T.; Lee, S. and Taylor, J. Amplification and direct sequencing of fungal ribosomal RNA genes for phylogenetics. In PCR Protocols: A Guide to Methods and Applications; Innis, M.A., Gelfand, D.H., Sninsky, J.J., White, T.J., Eds.; Academic Press: San Diego, CA, USA, 1990; pp. 315-322.

31. Pangallo, D.; Simonovičová, A.; Chovanova, K.; Ferianc, P. Wooden art objects and the museum environment: Identification and biodegradative characteristics of isolated microflora. Soc. Appl. Microbiol. Lett. Appl. Microbiol. 2007, 45, 87-94. [CrossRef]

32. Omar, A.M.; Taha, A.S.; Mohamed, A.A.; El-Wekeel, F. Fumigation is the ideal method in treating damaged archaeological paper using Ceratophyllum demersum L extract: A case study. J. Basic Environ. Sci. 2019, 6, 17-22. 